\title{
会員の皆㭏
}

○入会・転居・休会のご案内・

\section{1. 入会で案内}

入会ご希望の方は申込み書一式を電話, FAXあるいは葉 書にて事務局までご請求ください.

入会金 5,000円

年会費 15,000円（専門医，新専門医）

10,000 円 (非専門医, 協力会員, 外国人会員)

\section{2. 脳神経外科ジャーナル送付についてのお断り}

機関誌“脳神経外科ジャーナル”を年間 12 冊発行し, 入 会された時点から送付させていただきます，ただし，入会時 以前に発行されたその年度分の機関誌については送付されま せん. ご了承ください.

\section{3. 会費の納入期について}

当該年度の会費は総会の開かれた年の年末までに納入する ようご協力ください.

\section{4. 会費長期末納の方へ}

分割支払もお受けしたいと思いますので, 事務局へご相談 ください.

\section{5. 転居・転任される方へ}

転居・転任される方は速やかに学会事務局までご一報くだ さい.

\section{6. 国外留学される方へ}

国外留学される方は, 留学予定期間・留守中連絡方法およ び送付先などを渡航前に学会事務局までご一報ください，留 学期間中, 休会という形をとられますと, その期間の “脳神 経外科ジャーナル”をお受け取りになれません，機関誌をご 希望の方は，会費をあらかじめ全納いただくか，各年度每に 納入してください.

\section{日本脳神経外科コンブレス事務局} 干113-8421 東京都文京区本郷 2-1-1

順天堂大学医学部脳神経外科内

TEL 03-3813-1039 FAX 03-5684-3096

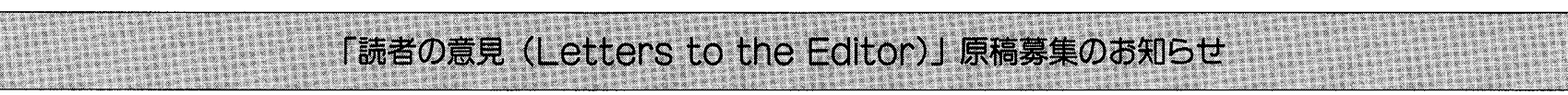

本誌では「読者の意見 (Letters to the Editor)」 欄を新しく設けました．読者交流の場として意見交換に ご利用いただきたく，下記の要領で編集室宛に原稿をお 寄せください.

趣 旨：(1)掲載論文に対する意見，(2)編集方針に対す る意見，希望などを揭載いたします。(1)に関 しては著者側からのコメントも揭載いたしま व.

執筆内容：(1)本文は図表も含め1,200 字以内（文献は 3 個以内, 写真・図・表は1個以内とし, その 数に応じて本文を減じてください)，(2)筆者
名，所属を明記，(3著者側からのコメントは 600 字以内

採否：編集委員会で決定いたします。不採用の場合 は速やかに連絡いたしますが，理由はお知ら せいたしません。 また，採否のいかんにかか わらず，原稿は返却いたしません。

その 他：論文掲載後 3 力月以内に意見をお寄せくださ い. 文章は畫簡の形式（口語体）としてくだ さい. 採用の場合は揭載誌 1 部をお送りいた します.

「脳神経外科ジャーナル」編集委員会 